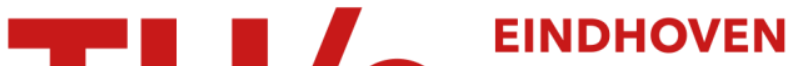 UNIVERSITY OF TECHNOLOGY
}

\section{Simultaneous NOx and particulate matter removal from diesel exhaust by hierarchical Fe-doped $\mathrm{Ce}-\mathrm{Zr}$-oxide}

Citation for published version (APA):

Cheng, Y., Song, W., Liu, J., Zheng, H., Zhao, Z., Xu, C., Wei, Y., \& Hensen, E. J. M. (2017). Simultaneous NOx and particulate matter removal from diesel exhaust by hierarchical Fe-doped Ce-Zr-oxide. ACS Catalysis, 7(6), 3883-3892. https://doi.org/10.1021/acscatal.6b03387

DOI:

10.1021/acscatal.6b03387

Document status and date:

Published: 01/06/2017

Document Version:

Accepted manuscript including changes made at the peer-review stage

Please check the document version of this publication:

- A submitted manuscript is the version of the article upon submission and before peer-review. There can be important differences between the submitted version and the official published version of record. People interested in the research are advised to contact the author for the final version of the publication, or visit the $\mathrm{DOI}$ to the publisher's website.

- The final author version and the galley proof are versions of the publication after peer review.

- The final published version features the final layout of the paper including the volume, issue and page numbers.

Link to publication

\section{General rights}

Copyright and moral rights for the publications made accessible in the public portal are retained by the authors and/or other copyright owners and it is a condition of accessing publications that users recognise and abide by the legal requirements associated with these rights.

- Users may download and print one copy of any publication from the public portal for the purpose of private study or research.

- You may not further distribute the material or use it for any profit-making activity or commercial gain

- You may freely distribute the URL identifying the publication in the public portal.

If the publication is distributed under the terms of Article 25fa of the Dutch Copyright Act, indicated by the "Taverne" license above, please follow below link for the End User Agreement:

www.tue.nl/taverne

Take down policy

If you believe that this document breaches copyright please contact us at:

openaccess@tue.nl

providing details and we will investigate your claim. 


\section{Simultaneous $\mathrm{NO}_{\mathrm{x}}$ and particulate matter removal from diesel exhaust by hierarchical Fe-doped Ce-Zr-oxide}

Ying Cheng, ${ }^{+,+}$Weiyu Song, ${ }^{\dagger}, \ldots+*$ Jian Liu, ${ }^{* \dagger}$ Huiling Zheng, ${ }^{\dagger}$ Zhen Zhao, ${ }^{*}$ Chunming $X u,{ }^{\dagger}$ Yuechang Wei, ${ }^{\dagger}$ Emiel J. M. Hensen ${ }^{*} " \|$

† State Key Laboratory of Heavy Oil Processing, China University of Petroleum, 18\#, Fuxue Road, Chang Ping, Beijing 102249, China.

"Schuit Institute of Catalysis, Department of Chemical Engineering and Chemistry, Eindhoven University of Technology, P.O.Box 513, 5600 M B, Eindhoven, the Netherlands.

$\S$ Institute of Catalysis for Energy and Environment, Shenyang Normal University, Shenyang 110034, China 


\begin{abstract}
Particulate matter and $\mathrm{NO}_{\mathrm{x}}$ emissions from diesel exhaust remains one of the most pressing environmental problems. We explore the use of hierarchically ordered mixed $\mathrm{Fe}-\mathrm{Ce}-\mathrm{Zr}$-oxides for the simultaneous capture and oxidation of soot and reduction of NOx by ammonia in a single step. The optimized material can effectively trap the model soot particles in its open macroporous structure and oxidize the soot below $400^{\circ} \mathrm{C}$, while completely removing $\mathrm{NO}$ in the $285^{\circ} \mathrm{C}-420^{\circ} \mathrm{C}$ range. Surface characterization and DFT calculations emphasize the defective nature of Fe-doped ceria. The isolated $\mathrm{Fe}$ ions and associated oxygen vacancies catalyze facile NO reduction to $\mathrm{N}_{2}$. A mechanism for the reduction of $\mathrm{NO}$ with $\mathrm{NH}_{3}$ on Fe-doped ceria is proposed involving adsorbed $\mathrm{O}_{2}$. Such adsorbed $\mathrm{O}_{2}$ species will also contribute to the oxidation of soot.
\end{abstract}

Keywords: soot oxidation; NOx reduction; ceria; doping; macropores 


\section{INTRODUCTION}

Air pollution due to exhaust gas emissions from transportation carries significant risk for human health and the environment. ${ }^{1-4}$ Introduced in the 1970's, the three-way catalytic convertor has become a widespread technology to remove noxious gases from gasoline-fueled cars. ${ }^{5}$ Precious group metals (PGMs) dispersed as nanoparticles on suitable oxide support materials can simultaneously oxidize $\mathrm{CO}$ and hydrocarbons and reduce NOx to less harmful gases. This technology cannot be used to remove NOx from the exhaust of diesel engines, because it is too rich in oxygen. Aside from NOx, diesel exhaust remains a major contributor to undesirable emissions of particulate matter (PM). Soot particles pose the most serious threat to human health. The major challenge in diesel exhaust clean-up is the removal of NOx under lean (oxygen-rich) conditions. ${ }^{67}$ Yoshida et al. were the first to propose the simultaneous removal of PM and NOx by a single catalytic material. ${ }^{8}$ Significant efforts have been made to develop suitable catalysts for this purpose. ${ }^{9}$ Current commercial solutions combine a diesel oxidation catalyst (DOC) for the removal of $\mathrm{CO}$ and hydrocarbons, a catalyzed diesel particulate filter (CDPF) for soot filtration and a selective catalytic reduction (SCR) step to remove NOx using a reducing gas such as ammonia. These operations are carried out in different compartments, thereby increasing the size and cost of this technology. Another drawback is that in some steps expensive PGMs such

as Pt are important catalyst ingredients. ${ }^{10,11}$ Consequently, there is significant 
incentive to develop novel approaches that rely on more abundant elements and combine one or more pollutant conversion steps. ${ }^{12}$

A potential alternative is to combine the CDPF and SCR functions in a selective catalytic reduction and particular filter (SCRPF). The particular challenge here is to achieve high rate of soot oxidation in combination with substantial NOx reduction at sufficiently low temperature. Therefore, it is necessary to identify materials with suitable redox abilities. Candidate materials are (mixed) metal oxides, 13,14 hydrotalcites, ${ }^{15}$ and alkali oxides. ${ }^{16}$ Besides high activity, increasing the contact area between the catalysts and solid reactant is a particular change in this field. ${ }^{17,18}$ It is also important that the texture of these materials is suitable for capturing soot particles, which are typically larger than $25 \mathrm{~nm}$. In such case, hierarchically structured oxides may be considered. Three-dimensionally ordered macroporous (3DOM) materials offer an ordered, inter-connected macroporous structure with openings suitable for the capture of soot particles. ${ }^{19}$

Ceria is well-known for its excellent oxygen storage capacity. ${ }^{20,21}$ The problem of low high-temperature stability of ceria structures can be overcome by introducing foreign elements into the ceria lattice, which also improves its redox properties. ${ }^{22-25}$ For instance, $\mathrm{Ce}-\mathrm{Zr}$ mixed oxides have been explored in the context of NOx reduction and soot oxidation. ${ }^{26-32}$ Other reports have already shown that doping Fe into ceria improves its reducibility, leading to more facile generation of oxygen vacancies at the surface important for soot oxidation and NOx reduction. ${ }^{33,34}$ 
Herein, we report for the first time about a Fe-doped 3DOM mixed Ce-Zr-oxide material that can simultaneously remove PM and NOx from diesel exhaust. Ammonia is used as a reductant for NOx. We prepared the 3DOM mixed oxides by a carbon-templating method and varied the Fe content in the mixed oxide. Optimized materials show good performance in simultaneous removal of soot and NOx at intermediate temperatures. The 3DOM mixed oxides are thermally stable and can be repeatedly regenerated without loss of activity. Density functional theory (DFT) calculations have been performed to understand the surface reducibility of the mixed oxides and gain insight into the role of Fe and surface oxygen vacancies in the reaction mechanism of NOx reduction and soot oxidation.

\section{EXPERIMENTAL SECTION}

Materials Synthesis. All starting chemicals were purchased from Sigma Aldrich and used without further purification. Carboxy-modified poly (methyl methacrylate) (c-PMMA) spheres were prepared by a modified emulsifier-free biphasic emulsion polymerization technique using initiators for the water and oil phase. ${ }^{35-37}$ Methylmethacrylate (MMA, $99 \%$ ) was the monomer used for obtaining PMMA spheres. Addition of acrylic acid (AA, >99 \%) monomer to the mixture allowed introducing carboxyl groups in the PMMA. Briefly, a four-necked, $1000 \mathrm{ml}$ round-bottomed flask was filled with the mixed solution of acetone $(80 \mathrm{ml},>98 \%)$, distilled water $(240 \mathrm{ml})$ and the monomers $(120 \mathrm{ml})$. The resulting mixture was heated 
to $80^{\circ} \mathrm{C}$ by a hot water bath. After about $30 \mathrm{~min}, 0.6 \mathrm{~g}$ of KPS (potassium persulfate, water-phase initiator, >99 \%) and $0.15 \mathrm{~g}$ of AIBN (azodiisobutyronitrile, oil-phase initiator, $98 \%$ ) mixed with $40 \mathrm{ml}$ of distilled water (preheated to $80^{\circ} \mathrm{C}$ ) were added. The whole solution was stirred at a constant speed of $350 \mathrm{~min}^{-1}$ for about $2 \mathrm{~h}$ with $\mathrm{N}_{2}$ bubbling. The obtained latex was cooled to room temperature and then centrifuged. The solid material was dried at room temperature (c-PMMA).

Three-dimensionally ordered macroporous (3DOM) $\mathrm{Ce}_{0.9-\mathrm{x}} \mathrm{Fe}_{\mathrm{x}} \mathrm{Zr}_{0.1} \mathrm{O}_{2}$ catalysts were prepared by carboxy-modified colloidal crystal templating (CMCCT). $\mathrm{Ce}\left(\mathrm{NO}_{3}\right)_{3} \cdot 6 \mathrm{H}_{2} \mathrm{O}(99.5 \%), \mathrm{Fe}\left(\mathrm{NO}_{3}\right)_{3} \cdot 9 \mathrm{H}_{2} \mathrm{O}(99.99 \%)$ and $\mathrm{ZrOCl}_{2} \cdot 8 \mathrm{H}_{2} \mathrm{O}(98 \%)$ were used as precursors for obtaining mixed metal oxides. Suitable amounts of $\mathrm{Ce}\left(\mathrm{NO}_{3}\right)_{3} \cdot 6 \mathrm{H}_{2} \mathrm{O}, \mathrm{Fe}\left(\mathrm{NO}_{3}\right)_{3} \cdot 9 \mathrm{H}_{2} \mathrm{O}$ and $\mathrm{ZrOCl}_{2} \cdot 8 \mathrm{H}_{2} \mathrm{O}$ were first dissolved in a mixture of ethylene glycol and methanol followed by vigorous stirring for $40 \mathrm{~min}$. Then, this solution was contacted with the c-PMMA hard template for $12 \mathrm{~h}$. After impregnation, the final material was subjected to vacuum filtration to remove excess precursor solution. The precipitate was dried at $50^{\circ} \mathrm{C}$ in a vacuum oven, calcined in inert (Ar) atmosphere at $130^{\circ} \mathrm{C}$ for $1 \mathrm{~h}$, followed by increasing the temperature to $600^{\circ} \mathrm{C}$ at a rate of $1^{\circ} \mathrm{C} / \mathrm{min}$. After a dwell of $5 \mathrm{~h}$, the atmosphere was changed to air and the sample was kept at $600^{\circ} \mathrm{C}$ for another $3 \mathrm{~h}$. The first step in Ar pyrolyzes the carbon: the $\mathrm{sp}^{2}$-hybridized carbon atoms are converted to a sturdy amorphous carbon material, which acts as the hard template for the in- situ formation of the 3DOM mixed oxide. The carbon template was finally removed by calcination in air. 
Catalyst Characterization. The crystal structure of the samples was investigated by powder X-ray diffraction (XRD) spectrometer (Shimadzu XRD 6000) with $\mathrm{Cu} \mathrm{K} \alpha$ radiation $\left(0.02^{\circ}\right.$ intervals in the range $5 \sim 90^{\circ}$ at a rate of $\left.4 \% \mathrm{~min}\right)$. Nitrogen adsorption isotherms were measured using a Micromeritics TriStar-II 3020 instrument. SEM (FEI Quanta200F) was conducted to analyze the surface morphology of the samples. The microstructure and lattice parameters were analyzed by TEM (JEOL JEM 2100 electron microscope). Raman spectra were collected in the anti-Stokes range of $100-2000 \mathrm{~cm}^{-1}$ using an inVia Reflex-Renishaw spectrometer. The sample was excited using a He-Gd laser (excitation wavelength $532 \mathrm{~nm}$ ). X-ray photoelectron spectra were measured on a XPSPHI-1600 ESCA spectrometer using an $\mathrm{Al} \mathrm{K} \alpha$ anode $(\mathrm{h} v=1253.6 \mathrm{eV})$ as the $\mathrm{X}$-ray source and using $\mathrm{C} 1 \mathrm{~s}$ at $284.6 \mathrm{eV}$ as an internal binding energy standard. Temperature-programmed desorption of ammonia ( $\mathrm{NH}_{3}$-TPD) was carried out in a conventional flow apparatus using a thermal conductivity detector. Temperature-programmed reduction with $\mathrm{H}_{2}\left(\mathrm{H}_{2}-\mathrm{TPR}\right)$ measurements were done in an Autosorb IQ Quantachrome apparatus.

Catalytic activity measurements. Catalytic activity measurements were done in a fixed-bed reactor. Printex U carbon black (Orion Engineered Carbons) was used as a model for particulate matter. This carbon black has an average particle size of $25 \mathrm{~nm}$ and a surface area of $100 \mathrm{~m}^{2} / \mathrm{g}$. Prior to each catalytic activity test, $100 \mathrm{mg}$ catalyst and $10 \mathrm{mg}$ Printex $\mathrm{U}$ were mixed gently with a spatula (loose contact mode). Thereafter, the mixture was placed between quartz wool plugs in a quartz tubular 
reactor with an inner diameter of $10 \mathrm{~mm}$. The reactor feed was comprised of 1000 ppm NO, 1000 ppm $\mathrm{NH}_{3}$ and $3 \% \mathrm{O}_{2}$ with $\mathrm{N}_{2}$ as the balance gas. In some cases, $5 \%$ $\mathrm{H}_{2} \mathrm{O}$ was added to the reactor feed to evaluate the influence of moisture. The gas-hourly space velocity (GHSV) was $25,000 \mathrm{~h}^{-1}$ with a total flow $100 \mathrm{ml} / \mathrm{min}$ at standard pressure and temperature. The performance of the optimum catalyst was also evaluated at higher GHSV by decreasing the catalyst amount. The concentrations of $\mathrm{NH}_{3}, \mathrm{NO}, \mathrm{NO}_{2}, \mathrm{~N}_{2} \mathrm{O}, \mathrm{CO}_{2}$ and $\mathrm{CO}$ were monitored at the outlet by online infrared spectroscopy (Thermo Is50 FTIR, equipped with a $2.4 \mathrm{~m}$ gas cell). For quantification, a robust method for multi-component gas analysis was used using the TQ Analyst software and making use of calibration curves based on mixtures of the relevant gases in different concentration ranges. ${ }^{38}$ Before each catalytic activity measurement, the catalyst sample was first swept by a flow of $100 \mathrm{ml} / \mathrm{min} \mathrm{N}_{2}$ for about $45 \mathrm{~min}$ prior to collecting a background IR spectrum of the reactor effluent. Afterwards, effluent IR spectra were recorded of the reactor feed that consisted of $1000 \mathrm{ppm} \mathrm{NH}_{3}, 1000 \mathrm{ppm}$ $\mathrm{NO}, 3 \% \mathrm{O}_{2}$ in $\mathrm{N}_{2}$ for $30 \mathrm{~min}$. Catalytic activity tests were carried out by heating the reactor bed from $30^{\circ} \mathrm{C}$ to $600^{\circ} \mathrm{C}$ at a rate of $3^{\circ} \mathrm{C} / \mathrm{min}$. The stability of the catalyst was evaluated by repeatedly evaluating its performance in this manner. For this purpose, $10 \mathrm{mg}$ Printex $\mathrm{U}$ was mixed with the catalyst bed. The absence of mass transfer limitations for the NO reduction reaction was verified by applying the Koros-Nowak criterion, while the absence of heat transfer due to soot oxidation was evaluated by Mears' criteria (see the Supporting Information). 
Computational Methods. DFT calculations were performed using the VASP code employing the GGA-PBE exchange-correlation potential. ${ }^{39}$ The valence electrons $(5 \mathrm{~s}, 4 \mathrm{f}, 3 \mathrm{~d}$ for $\mathrm{Ce} ; 2 \mathrm{~s}, 2 \mathrm{p}$ for $\mathrm{O}$ and $4 \mathrm{~s}, 3 \mathrm{~d}$ for $\mathrm{Fe}$ ) were expanded in a plane-wave basis set with a cut-off energy of $400 \mathrm{eV}$. The projector augmented wave method (PAW) was used to describe the effect of core electrons. ${ }^{40,41}$ The bulk equilibrium lattice constant of ceria $(5.49 \AA)$ previously calculated by $\mathrm{PBE}+\mathrm{U}\left(\mathrm{U}_{\text {eff }}=\right.$ $4.5 \mathrm{eV}$ ) was ued. ${ }^{42} 3 \times 3$ surface unit cell was used for $\mathrm{CeO}_{2}(111)$ surface. Fe atoms and the six top atomic layers of the ceria slab were allowed to relax, while the three bottom layers were kept fixed to their bulk position. The vacuum gap thickness was set to be $15 \AA$. Due to the large size the slab model (11.64 $\AA$ x $11.64 \AA$ ), a Monkhorst pack $1 \times 1 \times 1$ mesh was used for Brillouin zone integration. All structures were relaxed until the forces acting on each atom were smaller than $0.05 \mathrm{eV} / \AA$. To improve the description of the on-site Coulomb interactions in the Ce-f states and Fe-d states, a Hubbard correction was added. For Ce, a value of $U_{\text {eff }}=4.5 \mathrm{eV}$ was used for its $4 \mathrm{f}$ orbital. ${ }^{43-45}$ For Fe, a value of $U_{\text {eff }}=3.8 \mathrm{eV}$ was used for its $3 \mathrm{~d}$ orbital. ${ }^{46}$ The location and energy of transition states were calculated with the climbing-image nudged elastic band method (CINEB). ${ }^{47}$ Adsorption energies are expressed with reference to the adsorbing molecule in vacuum. The energies of all gas species were determined in a $15 \AA$ cubic box with a cut-off energy of $400 \mathrm{eV}$ at the $\Gamma$-point. 


\section{RESULTS AND DISCUSSION}

\section{Preparation and characterization}

The carboxy-modified variation of colloidal crystal templating using poly(methyl methacrylate) (c-PMMA) spheres is schematically depicted in Figure 1. ${ }^{35}$ The sturdy amorphous carbon material derived from PMMA pyrolysis can be used as a hard template for the fabrication of structured metal oxides. ${ }^{48}$ The carboxy modification of PMMA by using acrylic acid as a co-monomer was necessary to obtain a well-mixed Ce-Zr oxide structure. We prepared c-PMMA spheres by co-polymerization of MMA and AA using suitable initiators. Centrifuging and drying of the latex resulted in a highly ordered c-PMMA material. The structured oxides were obtained by impregnation of the solid organic template with a mixture of suitable precursor salts dissolved in a mixture of ethylene glycol and methanol, followed by pyrolysis at $600^{\circ} \mathrm{C}$ in inert and calcination in air to remove the organic part. TEM images show the ordered texture of the optimum $\mathrm{Ce}_{0.8} \mathrm{Fe}_{0.1} \mathrm{Zr}_{0.1} \mathrm{O}_{2}$ mixed oxide with macropores and uniformly sized walls (Figure $1 \mathrm{~b}-\mathrm{d}$ ) interconnected by smaller windows. ${ }^{49}$ All materials have the fluorite structure of ceria independent of the $\mathrm{Fe}$ and $\mathrm{Zr}$ content and no separate iron or zirconium oxide phases were detected by XRD (Figure S2). Small shifts in the main diffraction peaks for the mixed oxides compared to $\mathrm{CeO}_{2}$ evidence inclusion of $\mathrm{Fe}^{3+}$ and $\mathrm{Zr}^{4+}$ into the fluorite structure of ceria. High-resolution TEM images show (111) surface terminations, the d-spacing being consistent with that of ceria (Figure 1e). 

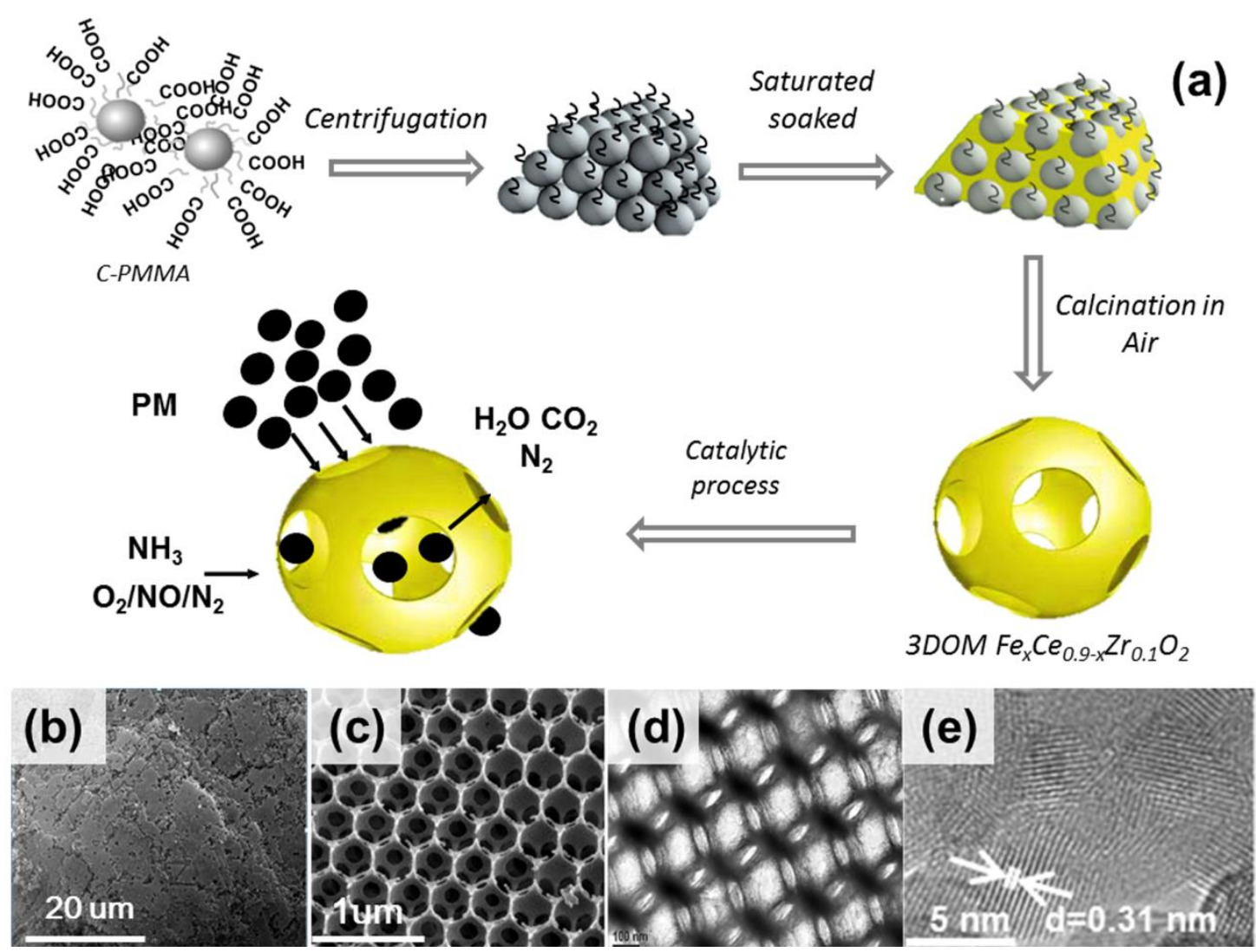

Figure 1. (a) Schematic representation of the synthesis of the 3DOM mixed $\mathrm{Ce}-\mathrm{Fe}-\mathrm{Zr}$ oxide and its catalytic function in diesel exhaust clean-up; Electron microscopy images: (b) SEM, (c, d, e) TEM images at different magnifications showing the macroporous structure (c, d) and the d-spacing of $\mathrm{CeO}_{2}(111)$.
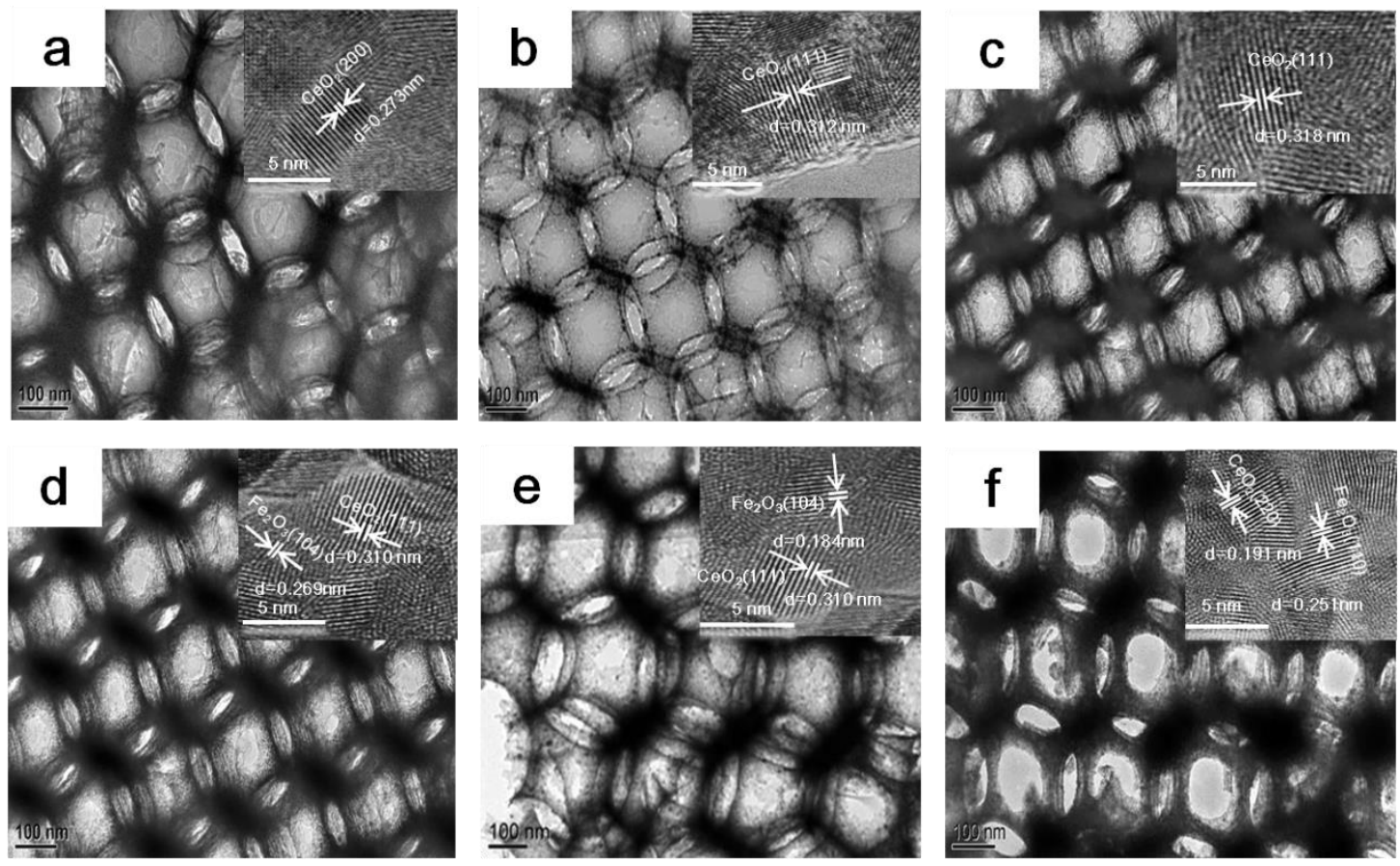
Figure 2. Representative TEM images of $3 \mathrm{DOM}$ materials: (a) $\mathrm{CeO}_{2}$, (b) $\mathrm{Ce}_{0.85} \mathrm{Fe}_{0.05} \mathrm{Zr}_{0.1} \mathrm{O}_{2}$, (c) $\mathrm{Ce}_{0.8} \mathrm{Fe}_{0.1} \mathrm{Zr}_{0.1} \mathrm{O}_{2}$, (d) $\mathrm{Ce}_{0.7} \mathrm{Fe}_{0.2} \mathrm{Zr}_{0.1} \mathrm{O}_{2}$, (e) $\mathrm{Ce}_{0.6} \mathrm{Fe}_{0.3} \mathrm{Zr}_{0.1} \mathrm{O}_{2}$ and (f) $\mathrm{Ce}_{0.5} \mathrm{Fe}_{0.4} \mathrm{Zr}_{0.1} \mathrm{O}_{2}$.

The introduction of $\mathrm{Fe}$ and $\mathrm{Zr}$ into the $\mathrm{CeO}_{2}$ lattice did not alter the 3DOM structure as long as the Fe substitution level was kept below 0.2 (Figure S3-S4). Introduction of more Fe led to segregated iron oxides observable in high-resolution TEM images (Figure 2). ${ }^{50}$ Raman spectra of the $3 \mathrm{DOM} \mathrm{Ce} 0.9-\mathrm{x} \mathrm{Fe}_{\mathrm{x}} \mathrm{Zr}_{0.1} \mathrm{O}_{2}$ samples contain an absorption band at $\sim 460 \mathrm{~cm}^{-1}$ due to the $\mathrm{F}_{2 \mathrm{~g}}$ mode of $\mathrm{CeO}_{2}$ (Figure 3). ${ }^{24,51}$ Only at higher Fe content $(\mathrm{x} \geq 0.2)$, Raman bands at $215 \mathrm{~cm}^{-1}$ and $280 \mathrm{~cm}^{-1}$ typical for Fe-O stretching vibrations in Fe-oxides appear. The nitrogen adsorption-desorption isotherms show a nearly linear correlation between the relative pressure and absorbed volume (Figure S4), which is the consequence of unrestricted monolayer-multilayer adsorption. The presence of a $\mathrm{H} 3$ hysteresis loop is a further indication of the macroporous structure. While the pure ceria material has a surface area of about 12 $\mathrm{m}^{2} / \mathrm{g}$ (Table S1), the mixed oxides have higher surface area, which is in part due to the presence of mesopores, evident from the hysteresis in the $\mathrm{p} / \mathrm{p}_{0}$ range between 0.4 and 0.8. These mesopores are likely occluded in the walls of the macroporous material. 


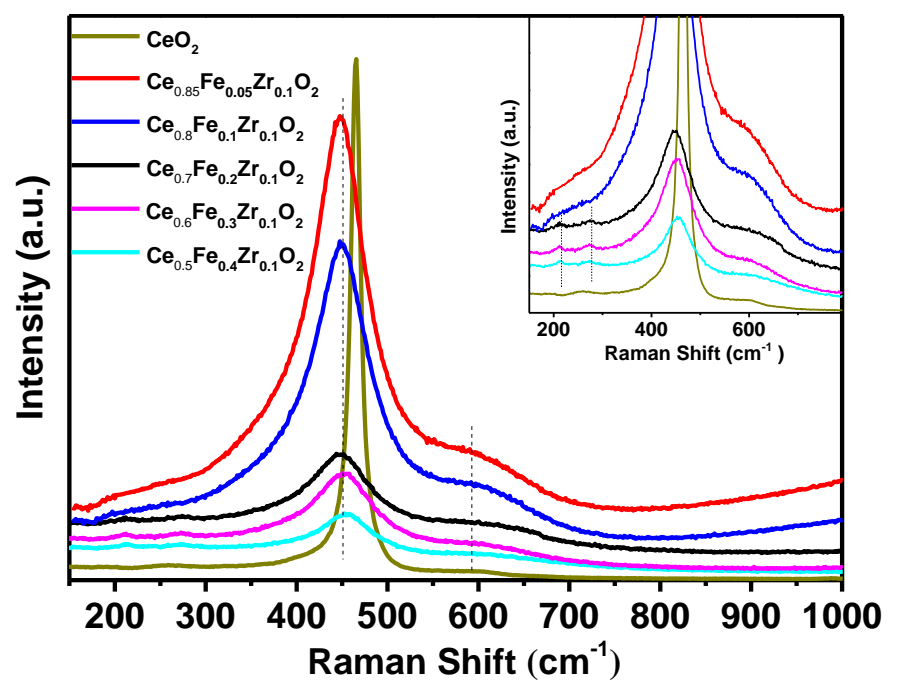

Figure 3. Raman spectra of the of $3 \mathrm{DOM}$ materials: (a) $\mathrm{CeO}_{2}$, (b) $\mathrm{Ce}_{0.85} \mathrm{Fe}_{0.05} \mathrm{Zr}_{0.1} \mathrm{O}_{2}$, (c) $\mathrm{Ce}_{0.8} \mathrm{Fe}_{0.1} \mathrm{Zr}_{0.1} \mathrm{O}_{2}$, (d) $\mathrm{Ce}_{0.7} \mathrm{Fe}_{0.2} \mathrm{Zr}_{0.1} \mathrm{O}_{2}$, (e) $\mathrm{Ce}_{0.6} \mathrm{Fe}_{0.3} \mathrm{Zr}_{0.1} \mathrm{O}_{2}$, (f) $\mathrm{Ce}_{0.5} \mathrm{Fe}_{0.4} \mathrm{Zr}_{0.1} \mathrm{O}_{2}$.
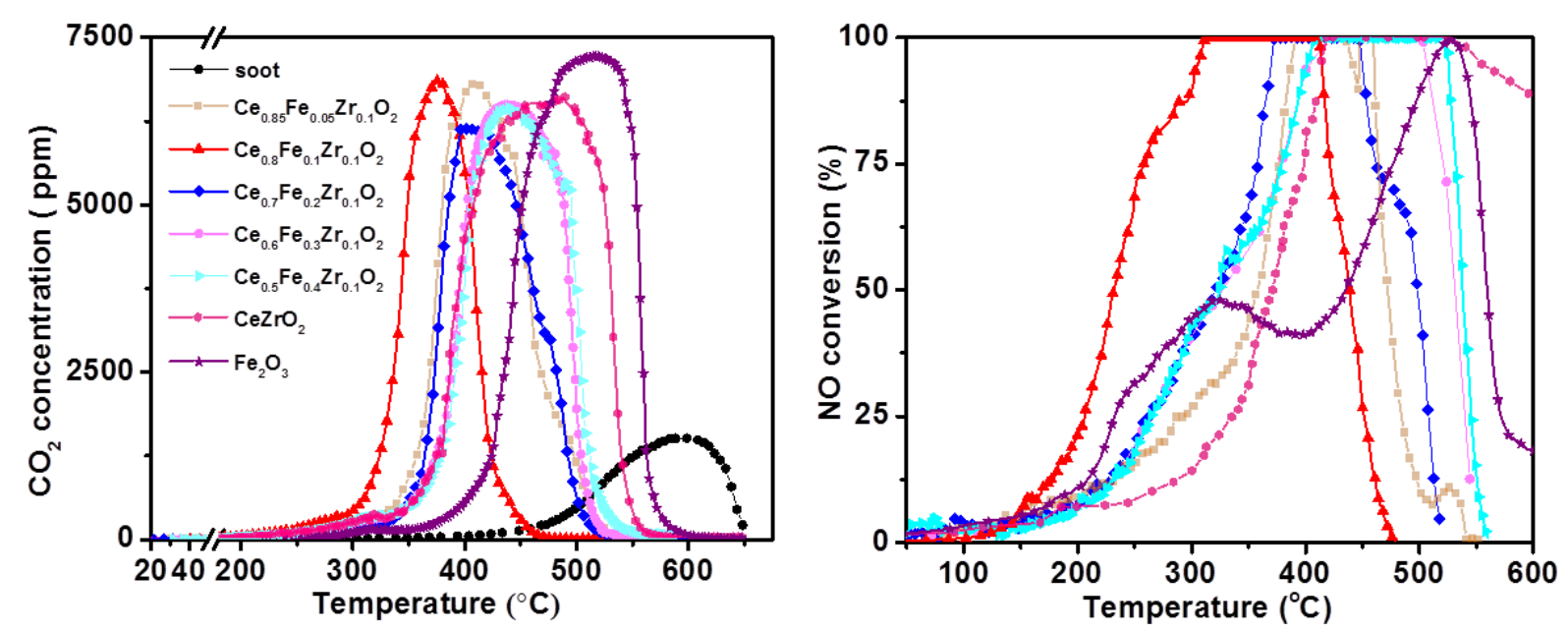

Figure 4. (left) $\mathrm{CO}_{2}$ concentration and (right) $\mathrm{NO}$ conversion as a function of temperature upon exposure of $3 \mathrm{DOM} \mathrm{Ce}_{0.9-\mathrm{x}} \mathrm{Fe}_{\mathrm{x}} \mathrm{Zr}_{0.1} \mathrm{O}_{2}$ catalysts loosely mixed with model soot particles in a gas feed containing 1000 ppm $\mathrm{NH}_{3}, 1000 \mathrm{ppm} \mathrm{NO}, 3 \% \mathrm{O}_{2}$ and balance $\mathrm{N}_{2}$ at a gas hourly space velocity of $25,000 \mathrm{~h}^{-1}$.

\section{Catalytic activity measurements}

Compared with ceria, mixed Ce-Zr oxides display better thermal stability and oxygen storage capacity, which is beneficial for PM combustion. ${ }^{52}$ In general, it is a challenge to reduce NOx under the oxygen-rich conditions required to oxidize PM 
into $\mathrm{CO}_{2} .{ }^{53}$ As $\mathrm{NO}_{2}$ is more effective in soot oxidation than $\mathrm{O}_{2}$, soot is usually first oxidized in the $\mathrm{NO}_{\mathrm{x}} / \mathrm{O}_{2}$ exhaust gas, followed by ammonia-assisted $\mathrm{NOx}$ reduction using, for instance, $\mathrm{Cu}$ /zeolites placed downstream of the PM combustion zone. ${ }^{54-57}$ Ammonia can be conveniently supplied to the after-treatment system by hydrolyzing urea. It has been demonstrated before that $\mathrm{Fe}$ is an active ingredient for $\mathrm{NO}_{\mathrm{x}}$ reduction. ${ }^{58}$

We optimized the $\mathrm{Fe}$ and $\mathrm{Zr}$ content of the 3DOM mixed Fe-Ce-Zr oxide towards low-temperature NOx reduction and complete soot oxidation. For this purpose, model soot particles with an average size of $25 \mathrm{~nm}$ were loosely mixed with the 3DOM mixed oxide catalysts and exposed to a simulated diesel exhaust feed containing 1000 ppm NO, $1000 \mathrm{ppm} \mathrm{NH}_{3}$ and 3\% $\mathrm{O}_{2}$ with balance $\mathrm{N}_{2}$ fed at a GHSV of $25,000 \mathrm{~h}^{-1}$. The loose contact mode provides a better approximation of soot trapping in a DPF than tight contact conditions involving grinding the components in a mortar. ${ }^{7}$ Figure 4 shows the transient behavior of the catalyst during temperature-programmed reaction. $\mathrm{CO}_{2}$ is produced by combustion of the model soot particles. The effluent $\mathrm{CO}_{2}$ concentration decreases at high temperature, as combustion of the model soot near completion. NO conversion at high temperature is limited because of the oxidation of $\mathrm{NH}_{3}$ (Figure S5). In low temperature $\mathrm{NH}_{3}-\mathrm{SCR}$, NO oxidation to $\mathrm{NO}_{2}$ is crucial to improve the rate of NOx removal via the fast SCR reaction. ${ }^{59,60}$ Besides, $\mathrm{NO}_{2}$ is also a more active soot oxidant than $\mathrm{NO} .{ }^{61}$ The $3 \mathrm{DOM}$ $\mathrm{Ce}_{0.8} \mathrm{Fe}_{0.1} \mathrm{Zr}_{0.1} \mathrm{O}_{2}$ catalyst shows shows excellent activity in the oxidation of NO to 
$\mathrm{NO}_{2}$ (Figure S6). The optimal catalyst $\mathrm{Ce}_{0.8} \mathrm{Fe}_{0.1} \mathrm{Zr}_{0.1} \mathrm{O}_{2}$ is effective for reducing NO by $90 \%$ in the range of $265-420^{\circ} \mathrm{C}$ and for completely oxidizing soot to $\mathrm{CO}_{2}$ at about $375^{\circ} \mathrm{C}$. Among the $3 \mathrm{DOM}$ mixed Fe-Ce-Zr-O catalysts (Table 1), the optimized material is able to oxidize coke below $400^{\circ} \mathrm{C}$. When the Fe content is too high, the performance was much lower, because segregated Fe-oxides block the surface of the solid Fe-Ce-Zr-O solution. ${ }^{62}$ Consistent with this, $\mathrm{Fe}_{2} \mathrm{O}_{3}$ itself showed low activity in PM oxidation and $\mathrm{NO}_{\mathrm{x}} \mathrm{SCR}$.

We also evaluated the performance of the catalyst in the presence of water. Adding $5 \% \mathrm{H}_{2} \mathrm{O}$ to the reactor feed, the catalytic performance for PM oxidation was decreased, while that for NOx reduction was only slightly lower in comparison to the experiments without water (Figure S7). Complete reduction of NO was achieved in the $343^{\circ} \mathrm{C}-426^{\circ} \mathrm{C}$ range, while soot was completely combusted at $421^{\circ} \mathrm{C}$. Clearly, water had a negative effect on low-temperature NO conversion, but improved NO reduction rate at high temperature. The strong influence of water on NO reduction is due to competitive adsorption of $\mathrm{NH}_{3}$ and $\mathrm{H}_{2} \mathrm{O}$. This limits $\mathrm{NH}_{3}$ adsorption on acid sites at low temperature, thus decreasing low temperature NOx reduction. On the other hand, at high temperature the inhibiting effect of $\mathrm{H}_{2} \mathrm{O}$ slows $\mathrm{NH}_{3}$ oxidation, resulting in higher NOx reduction rate.

As the used space velocity was relatively low with respect to diesel exhaust gas treatment, we also evaluated the performance of the optimum $3 \mathrm{DOM} \mathrm{Ce} 0{ }_{0.8} \mathrm{Fe}_{0.1} \mathrm{Zr}_{0.1} \mathrm{O}_{2}$ at higher space velocities (GHSV of 50,000 $\mathrm{h}^{-1}$ and $100,000 \mathrm{~h}^{-1}$ ). Figure S8 shows that 
under these more stringent conditions catalytic performance was decreased. Complete NOx conversion was still obtained in the $338^{\circ} \mathrm{C}-420^{\circ} \mathrm{C}$ temperature range at a GHSV of $50,000 \mathrm{~h}^{-1}$, whereas at the highest GHSV the maximum NO conversion was limited to $80 \%$. The $\mathrm{PM}$ combustion rate displayed maxima at $407^{\circ} \mathrm{C}$ and $435^{\circ} \mathrm{C}$ for GHSV values of $50,000 \mathrm{~h}^{-1}$ and $100,000 \mathrm{~h}^{-1}$.

Table 1. Performance of structured oxides in simultaneous NOx reduction and PM combustion (100 mg catalyst loosely mixed with $10 \mathrm{mg}$ Printex $\mathrm{U}$ model soot particles; 1000 ppm NO, $1000 \mathrm{ppm} \mathrm{NH}_{3}, 3 \% \mathrm{O}_{2}$ and balance $\mathrm{N}_{2}$ at a gas hourly space velocity of $\left.25,000 \mathrm{~h}^{-1}\right)$.

\begin{tabular}{lcc}
\hline Catalyst & $\mathrm{T}_{\max , \mathrm{CO} 2}{ }^{\mathrm{a}}\left({ }^{\circ} \mathrm{C}\right)$ & $\mathrm{T}_{\max , \mathrm{NO}}{ }^{\mathrm{b}}\left({ }^{\circ} \mathrm{C}\right)$ \\
\hline $\mathrm{Fe}_{2} \mathrm{O}_{3}$ & 514 & 526 \\
$\mathrm{CeZrO}_{2}$ & 477 & $418-523$ \\
$\mathrm{Ce}_{0.85} \mathrm{Fe}_{0.05} \mathrm{Zr}_{0.1}$ & 398 & $387-438$ \\
$\mathrm{Ce}_{0.8} \mathrm{Fe}_{0.1} \mathrm{Zr}_{0.1} \mathrm{O}_{2}$ & 375 & $285-410$ \\
$\mathrm{Ce}_{0.7} \mathrm{Fe}_{0.2} \mathrm{Zr}_{0.1} \mathrm{O}_{2}$ & 409 & $372-448$ \\
$\mathrm{Ce}_{0.6} \mathrm{Fe}_{0.3} \mathrm{Zr}_{0.1} \mathrm{O}_{2}$ & 433 & $404-510$ \\
$\mathrm{Ce}_{0.5} \mathrm{Fe}_{0.4} \mathrm{Zr}_{0.1} \mathrm{O}_{2}$ & 442 & $408-523$ \\
\hline${ }^{\mathrm{a}} \mathrm{Temperature} \mathrm{of} \mathrm{maximum} \mathrm{CO}_{2}$ concentration; \\
${ }^{\mathrm{b}} \mathrm{Temperature} \mathrm{range} \mathrm{where} \mathrm{NO}$ conversion is complete.
\end{tabular}



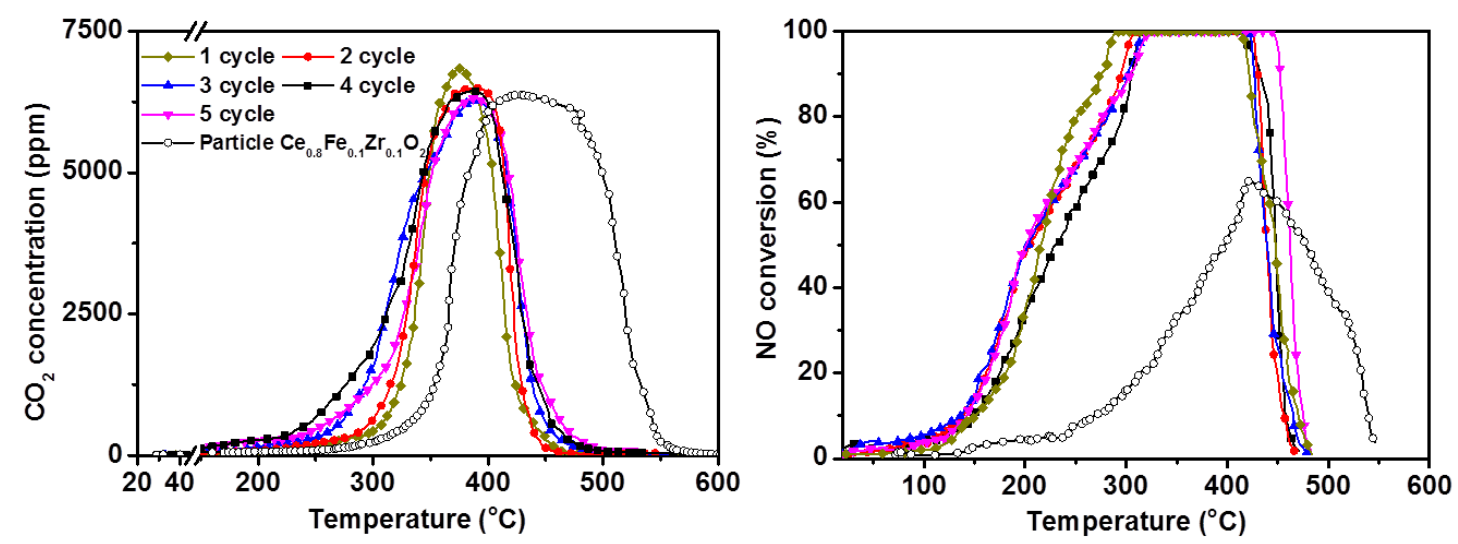

Figure 5. Re-use of the optimal $3 \mathrm{DOM} \mathrm{Ce}_{0.8} \mathrm{Fe}_{0.1} \mathrm{Zr}_{0.1} \mathrm{O}_{2}$ catalyst during five concessive cycles (the spent catalyst was mixed with new Printex U model soot particles and re-evaluated under similar conditions; GHSV $=25,000 \mathrm{~h}^{-1}, 1000 \mathrm{ppm}$ $\mathrm{NH}_{3}, 1000 \mathrm{ppm} \mathrm{NO}, 3 \% \mathrm{O}_{2}$ in $\mathrm{N}_{2}$, model soot/catalyst mass ratio 0.1 ).

Figure 5 shows that the optimized $3 \mathrm{DOM} \mathrm{Ce} \mathrm{C}_{0.8} \mathrm{Fe}_{0.1} \mathrm{Zr}_{0.1} \mathrm{O}_{2}$ catalyst can be re-used without loss of activity for five consecutive cycles with fresh model soot being added after each cycle. As in a real application the ceramic materials may be exposed to high temperatures, we also aged the optimum $3 \mathrm{DOM}$ mixed oxide at $900^{\circ} \mathrm{C}$ in air for $5 \mathrm{~h}$. This had only a minor effect on the catalytic performance (Figure S9), with a maximum rate of soot combustion being observed at $398^{\circ} \mathrm{C}$ and full $\mathrm{NO}$ conversion in the $327^{\circ} \mathrm{C}-420^{\circ} \mathrm{C}$ range. SEM shows that the texture of the $3 \mathrm{DOM}$ mixed oxide is largely retained, emphasizing its good thermal stability (Figure S10). Comparison of the catalytic performance of the optimum 3DOM catalyst to literature data emphasizes the outstanding performance in combined soot oxidation and NO reduction (Table S2). SEM images of the original and the catalyst used in five 
consecutive cycles demonstrates that the structured mixed oxide is thermally stable in the experiments (Figure 6).

Figure 5 also displays the performance of a non-templated mixed oxide of the same composition as the optimal one. Soot combustion is delayed too much higher temperatures, presumably because of the much less efficient contact of the soot particles with the surface of the mixed oxide. PM oxidation can enhance NOx reduction by involving $\mathrm{C}=\mathrm{O}$ groups on soot, which are intermediates in the complete oxidation of soot. ${ }^{63}$ Compared with the large pores of the $3 \mathrm{DOM}$ structure, the average pore size of the non-templated mixed oxide is only $15.8 \mathrm{~nm}$, too small for the model soot particles to enter. Thus, the soot particles can only interact with a much smaller portion of the mixed oxide surface. The strong influence of the texture together with the use of the loose mixing method suggests that the model soot particles will enter the pores of the 3DOM structure during the performance test. This supposition is confirmed by studying a 3DOM sample that was only heated to $250^{\circ} \mathrm{C}$. Figure 6 shows TEM images of the model soot as well as a soot particle trapped in the large pores of the $3 \mathrm{DOM}$ structure after heating to $250^{\circ} \mathrm{C}$. On the other hand, also the rate of reduction of NO was substantially lower for the non-structured mixed oxide catalyst. As its surface area is higher than that of the 3DOM mixed oxide, the lower performance suggests that the surface of the non-templated mixed oxide has a different composition, likely containing less Fe sites. 

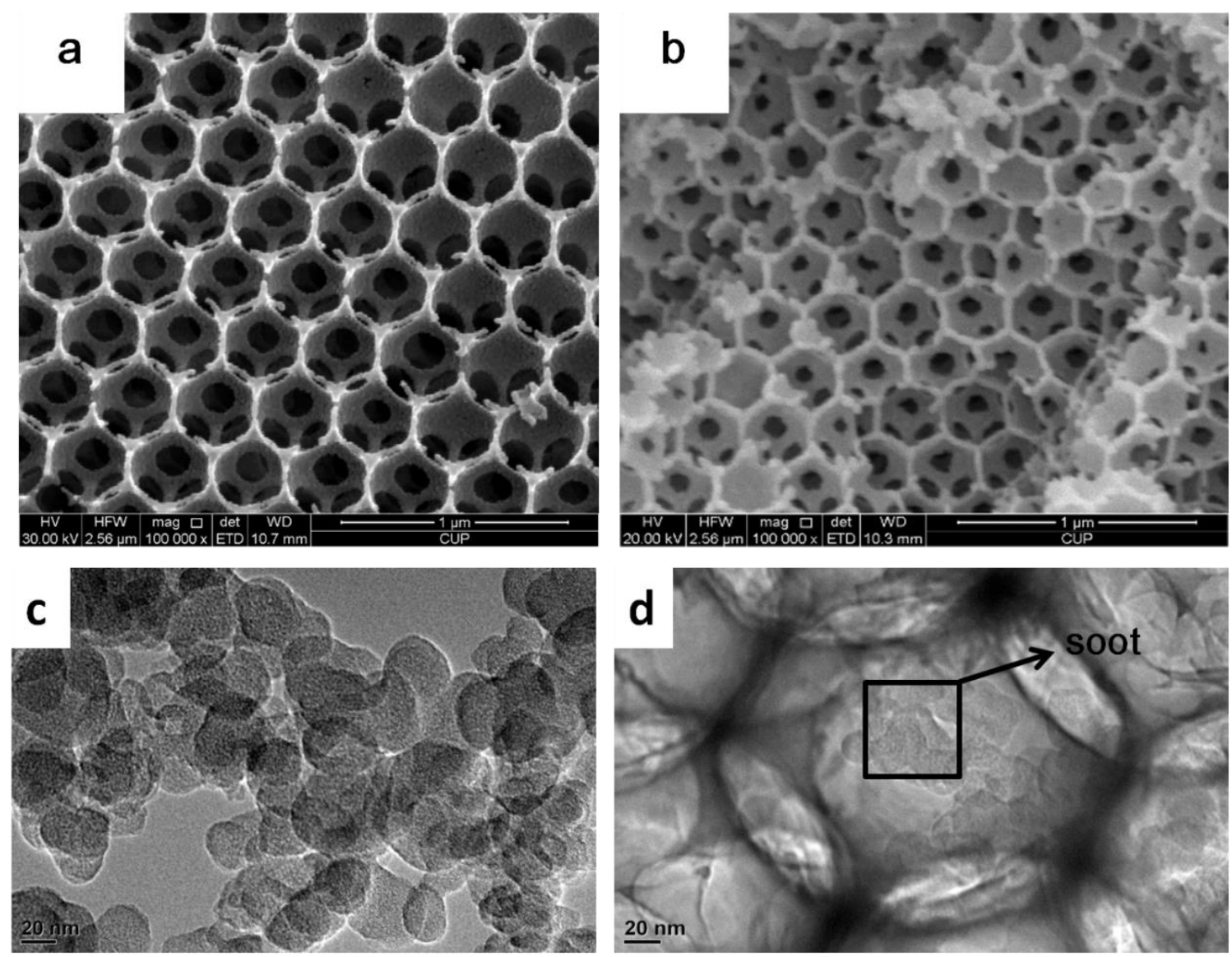

Figure 6. SEM of the (a) fresh and (b) spent optimal $3 \mathrm{DOM} \mathrm{Ce} 0.8 \mathrm{Fe}_{0.1} \mathrm{Zr}_{0.1} \mathrm{O}_{2}$ catalyst after five cycles; TEM images of (c) Printex $\mathrm{U}$ and (d) $3 \mathrm{DOM} \mathrm{Ce} \mathrm{e}_{0.8} \mathrm{Fe}_{0.1} \mathrm{Zr}_{0.1} \mathrm{O}_{2}$ catalyst mixed with Printex $\mathrm{U}$ after temperature programmed oxidation until $250^{\circ} \mathrm{C}$ (reaction conditions: GHSV $=$ 25,000 $\mathrm{h}^{-1}, 1000 \mathrm{ppm} \mathrm{NH}_{3}, 1000 \mathrm{ppm} \mathrm{NO}, 3 \% \mathrm{O}_{2}$ in $\mathrm{N}_{2}$, model soot/catalyst mass ratio 0.1). 


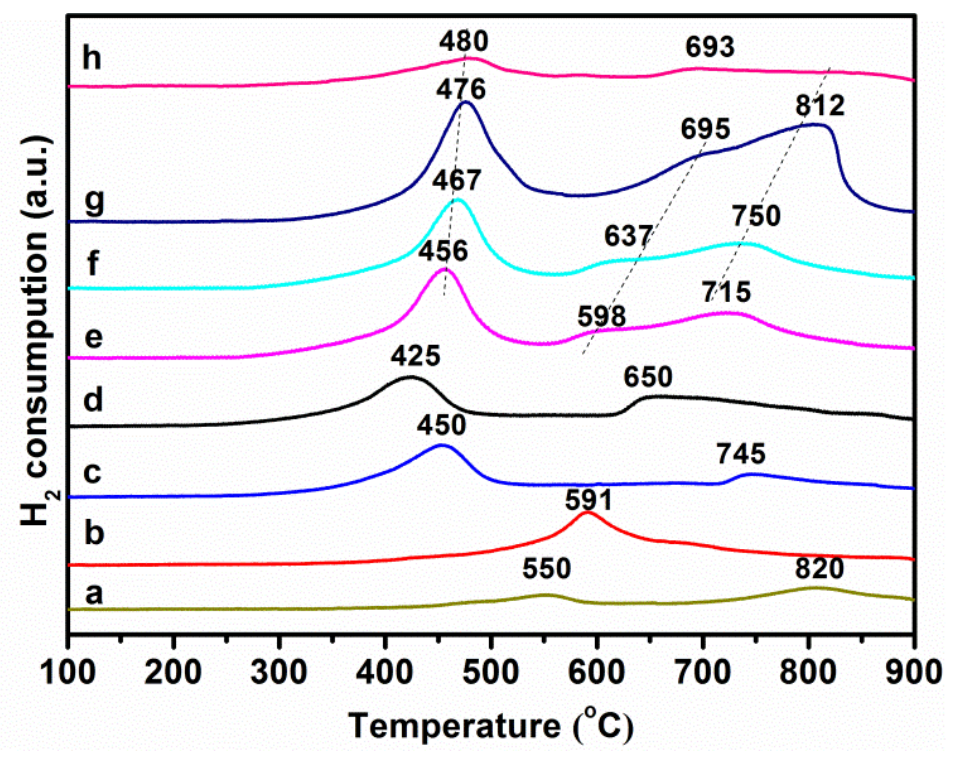

Figure 7. $\mathrm{H}_{2}$-TPR traces of the $3 \mathrm{DOM}$ materials: (a) $\mathrm{CeO}_{2}$, (b) $\mathrm{CeZrO}_{2}$, (c) $\mathrm{Ce}_{0.85} \mathrm{Fe}_{0.05} \mathrm{Zr}_{0.1} \mathrm{O}_{2}$, (d) $\mathrm{Ce}_{0.8} \mathrm{Fe}_{0.1} \mathrm{Zr}_{0.1} \mathrm{O}_{2}$, (e) $\mathrm{Ce}_{0.7} \mathrm{Fe}_{0.2} \mathrm{Zr}_{0.1} \mathrm{O}_{2}$, (f) $\mathrm{Ce}_{0.6} \mathrm{Fe}_{0.3} \mathrm{Zr}_{0.1} \mathrm{O}_{2}$, and (g) $\mathrm{Ce}_{0.5} \mathrm{Fe}_{0.4} \mathrm{Zr}_{0.1} \mathrm{O}_{2}$ and (h) non-templated $\mathrm{Ce}_{0.8} \mathrm{Fe}_{0.1} \mathrm{Zr}_{0.1} \mathrm{O}_{2}$
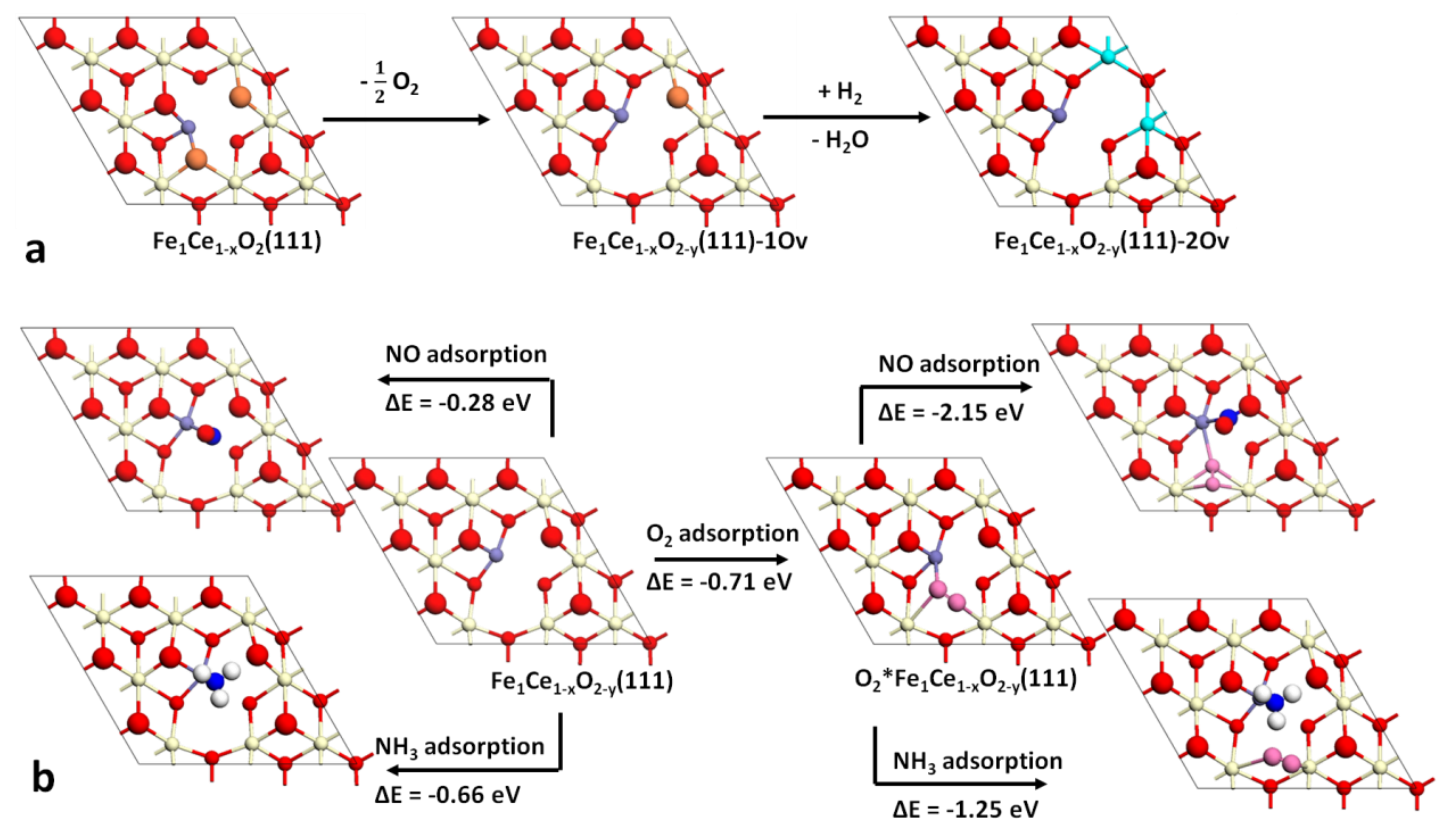

Figure 8. (a) Structure of Fe-doped $\mathrm{CeO}_{2}(111)$ as the stoichiometric surface and with one and two oxygen vacancies; (b) The adsorption of $\mathrm{NH}_{3}$ and $\mathrm{NO}$ on Fe-doped $\mathrm{CeO}_{2}(111)$ with one oxygen vacancy $\left(\mathrm{Fe}_{1} \mathrm{Ce}_{1-\mathrm{x}} \mathrm{O}_{2-\mathrm{y}}(111)\right)$; Fe-doped $\mathrm{CeO}_{2}(111)$ with the oxygen vacancy pre-adsorbed by $\mathrm{O}_{2}\left(\mathrm{O}_{2} * \mathrm{Fe}_{1} \mathrm{Ce}_{1-\mathrm{x}} \mathrm{O}_{2-\mathrm{y}}(111)\right)$. (color scheme: white 
$-\mathrm{Ce}^{4+}$; green $-\mathrm{Ce}^{3+}$; red $-\mathrm{O}$; Orange $-\mathrm{O}$ to be removed; purple $-\mathrm{Fe}$; blue $-\mathrm{N}$; bright white $-\mathrm{H}$ ).

Temperature-programmed reduction $\left(\mathrm{H}_{2}-\mathrm{TPR}\right)$ profiles of $3 \mathrm{DOM} \mathrm{Ce}_{0.9-\mathrm{x}} \mathrm{Fe}_{\mathrm{x}} \mathrm{Zr}_{0.1} \mathrm{O}_{2}$ catalysts demonstrate the better reducibility of the Fe-doped $\mathrm{Ce}-\mathrm{Zr}$ mixed oxides compared with $\mathrm{CeO}_{2}$ and $\mathrm{Ce}-\mathrm{Zr}$ oxide (Figure 7). The 3DOM ceria sample shows two reduction maxima at $550^{\circ} \mathrm{C}$ and $820^{\circ} \mathrm{C}$ due to surface and bulk reduction. The mixed $\mathrm{CeZrO}_{2}$ sample shows one reduction feature at $591^{\circ} \mathrm{C}$. Inclusion of $\mathrm{Zr}$ in the ceria lattice is known to increase the reducibility of the bulk of ceria. ${ }^{64,65}$ An additional low-temperature reduction feature in the $425-476^{\circ} \mathrm{C}$ range appears in the $\mathrm{Fe}$-doped mixed oxides. It occurs at the lowest temperature for the best-performing $\mathrm{Ce}_{0.8} \mathrm{Fe}_{0.1} \mathrm{Zr}_{0.1} \mathrm{O}_{2}$ sample. The high-temperature reduction features observed for samples at higher Fe content are due to reduction of $\mathrm{Fe}_{2} \mathrm{O}_{3} .{ }^{66,67}$ In line with the low NO SCR performance of the non-templated mixed oxide, TPR shows that the surface reduction occurs at relatively high temperature and with relatively low hydrogen consumption. This suggests that a relatively small part of $\mathrm{Fe}$ is built into the ceria, indicating that the CMCCT method is conducive in generating highly dispersed Fe species in the ceria surface.

\section{DFT calculations}

To better understand how doping with Fe enhances the reducibility of ceria and catalytic performance, we performed DFT+U calculations using a $\mathrm{CeO}_{2}(111)$ surface model in which one $\mathrm{Ce}$ atom was substituted by a Fe atom. We choose the (111) 
surface, as it is the most stable termination of ceria. We studied the oxygen formation energy of Fe-doped ceria as well as a reaction mechanism for the oxidation of NO to $\mathrm{N}_{2}$ by $\mathrm{NH}_{3}$ and $\mathrm{O}_{2}$. Finally, we also discuss the role of adsorbed $\mathrm{O}_{2}$ in the oxidation of coke.

Compared with the high oxygen vacancy formation energy of the stoichiometric (111) surface of ceria $(2.1 \mathrm{eV}, 1 \mathrm{eV} \approx 96 \mathrm{~kJ} / \mathrm{mol})$, removing an oxygen atom from the Fe-doped $\mathrm{CeO}_{2}(111)$ surface is exothermic by $-0.10 \mathrm{eV}$. This result implies that the ceria surface will already contain oxygen vacancies. The energy to remove a second $\mathrm{O}$ atom close to the first one is $1.39 \mathrm{eV}$, which is still substantially lower than the oxygen vacancy formation energy of the stoichiometric ceria surface. Thus, the first reduction feature observed in the $\mathrm{H}_{2}$-TPR traces of the Fe-doped samples is due to the removal of a second $\mathrm{O}$ atom close to the Fe substitution. The DFT calculations predict that removing this $\mathrm{O}$ atom results in two $\mathrm{Ce}^{3+}$ surface atoms (Figure 8a). In keeping with this, XPS confirms that the Fe-containing samples contain more $\mathrm{Ce}^{3+}$ than the Fe-free reference sample (Table 2). The highest $\mathrm{Ce}^{3+} / \mathrm{Ce}^{4+}$ ratio was observed for the most active sample. XPS also demonstrates that the surface contains the highest amount of surface adsorbed oxygen, in the form of $\mathrm{O}_{2}{ }^{2-}$ and $\mathrm{O}^{-}$. We speculate that the oxygen species at higher binding energy are due to molecular oxygen, strongly adsorbed on oxygen vacancies in close proximity to the Fe dopant in the ceria surface. DFT calculations show that molecular $\mathrm{O}_{2}$ strongly adsorbs to the defective Fe-substituted ceria surface, forming $\mathrm{O}_{2}{ }^{2-}$ species $\left(\mathrm{E}_{\mathrm{ads}}=-0.71 \mathrm{eV}\right.$, Figure $\left.8 \mathrm{~b}\right)$. 
Table 2. Surface composition and oxidation state for the 3DOM materials as probed by XPS.

\begin{tabular}{|c|c|c|c|c|c|c|c|}
\hline \multirow{3}{*}{ Catalyst } & \multirow{2}{*}{\multicolumn{3}{|c|}{ Ce $4 \mathrm{f}$ envelope }} & \multicolumn{3}{|c|}{ O 1s envelope } & \multirow{3}{*}{ Ratio $^{\mathbf{a}}$} \\
\hline & & & & \multicolumn{2}{|c|}{ Surface 0} & \multirow{2}{*}{$\begin{array}{c}\text { Lattice O } \\
\mathbf{O}^{2-}(\%) \\
\end{array}$} & \\
\hline & $\mathrm{Ce}^{3+}(\%)$ & $\mathrm{Ce}^{4+}(\%)$ & $\mathrm{Ce}^{3+} / \mathrm{Ce}^{4+}$ & $\mathbf{O}^{-}(\%)$ & $\mathrm{O}_{2}^{-}(\%)$ & & \\
\hline $\mathrm{CeZrO}_{2}$ & 21.1 & 78.9 & 0.267 & 7.4 & 19.4 & 73.2 & 0.366 \\
\hline $\mathrm{Ce}_{0.85} \mathrm{Fe}_{0.05} \mathrm{Zr}_{0.1} \mathrm{O}_{2}$ & 26 & 74.1 & 0.351 & 4.6 & 30.5 & 64.9 & 0.541 \\
\hline $\mathrm{Ce}_{0.8} \mathrm{Fe}_{0.1} \mathrm{Zr}_{0.1} \mathrm{O}_{2}$ & 26.3 & 73.7 & 0.357 & 4.7 & 30.7 & 64.6 & 0.548 \\
\hline $\mathrm{Ce}_{0.7} \mathrm{Fe}_{0.2} \mathrm{Zr}_{0.1} \mathrm{O}_{2}$ & 24.9 & 75.1 & 0.331 & 11.8 & 22.6 & 65.6 & 0.524 \\
\hline $\mathrm{Ce}_{0.6} \mathrm{Fe}_{0.3} \mathrm{Zr}_{0.1} \mathrm{O}_{2}$ & 23.5 & 76.5 & 0.307 & 8.9 & 23.8 & 67.3 & 0.486 \\
\hline $\mathrm{Ce}_{0.5} \mathrm{Fe}_{0.4} \mathrm{Zr}_{0.1} \mathrm{O}_{2}$ & 23 & 77 & 0.299 & 6.2 & 24.5 & 69.3 & 0.443 \\
\hline
\end{tabular}

${ }^{\text {a }}$ Ratio of surface and lattice oxygen.

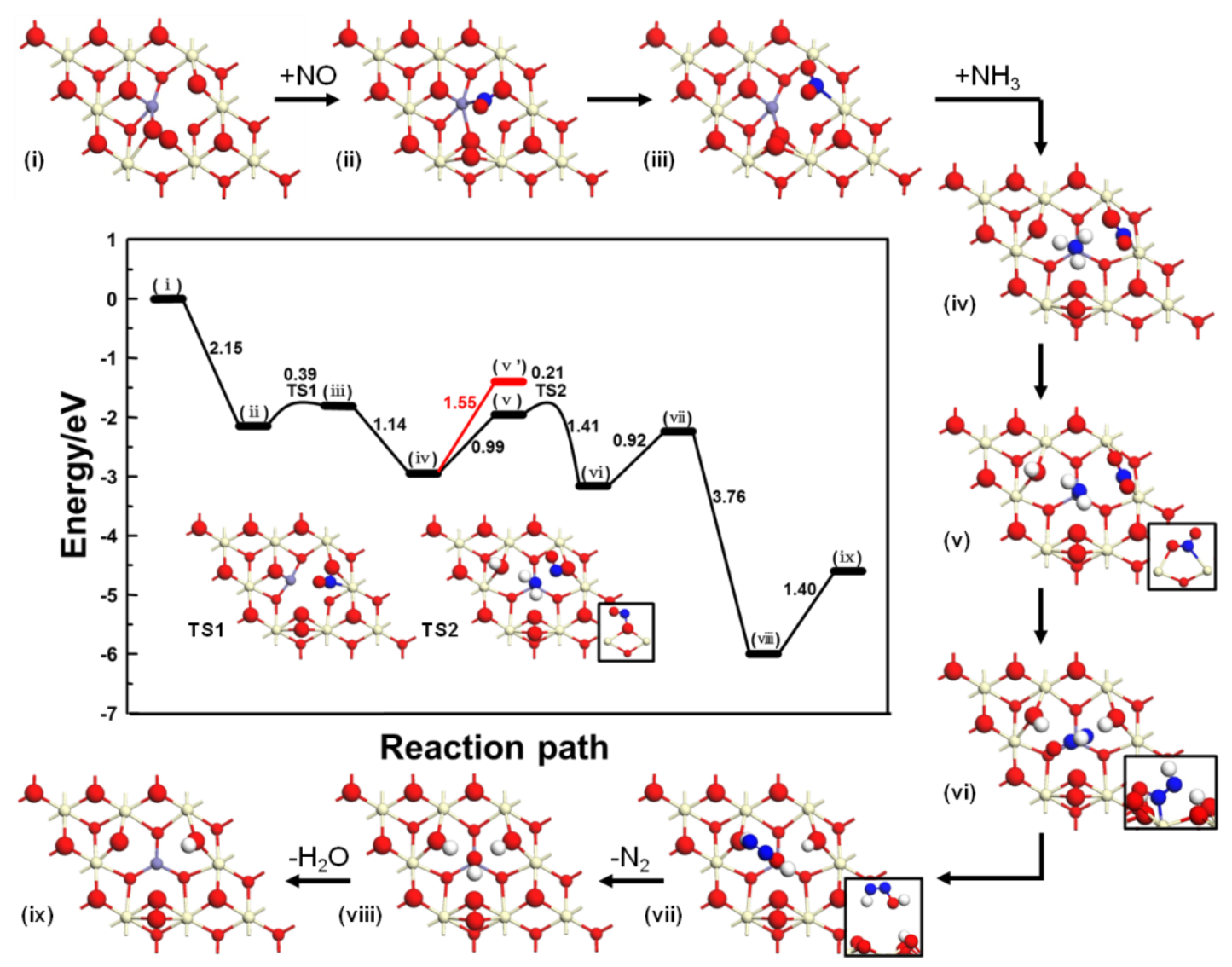


Figure 9. Potential energy diagram of NO reduction with key reaction intermediates. State $\mathrm{v}$ and $\mathrm{v}$ ' represent $\mathrm{N}-\mathrm{H}$ dissociation in adsorbed $\mathrm{NH}_{3}$ by lattice $\mathrm{O}$ and adsorbed $\mathrm{O}_{2}$, respectively.

The combined results of surface characterization and catalytic testing emphasize the unique properties of $\mathrm{Fe}$ atoms doped into ceria towards $\mathrm{NO}$ reduction with $\mathrm{NH}_{3}$ combined with soot oxidation. To gain better insight into the role of ceria doping with $\mathrm{Fe}$, we investigated the mechanism of $\mathrm{NO}$ reduction by $\mathrm{NH}_{3}$ by DFT calculations (Figure 9). We started the catalytic cycle from the stable surface under oxygen-rich conditions, i.e., the surface that contains $\mathrm{O}_{2}$ adsorbed on the oxygen vacancy close to the Fe site (state i). NO strongly adsorbs on the exposed Lewis acid Fe site (state ii, $\left.\Delta \mathrm{E}_{\mathrm{ads}}=-2.15 \mathrm{eV}\right)$. The adsorbed $\mathrm{NO}$ molecule will easily react with a ceria lattice $\mathrm{O}$ atom to form nitrite (state iii). The activation barrier determined by the climbing image nudged elastic band method is $0.39 \mathrm{eV}$. Although state iii is slightly less stable than state ii, the formation of the nitrite species allows $\mathrm{NH}_{3}$ to adsorb on the Lewis acid Fe site. This adsorption is strong with $\Delta \mathrm{E}_{\mathrm{ads}}=-1.14 \mathrm{eV}$ (state iv). The formation of nitrite stores $\mathrm{NO}$ on the surface and alleviates the competition between NO and $\mathrm{NH}_{3}$ for adsorption on the catalytic surface. This Langmuir-Hinshelwood mechanism is entropically favored over the Eley-Rideal alternative involving direct reaction of $\mathrm{NO}$ from the gas phase with a lattice $\mathrm{O}$ atom. $\mathrm{NH}_{3}$-TPD confirms that ammonia is stronger adsorbed on the Fe-doped samples than on Fe-free samples (Figure S12).

An aspect worth discussing is that the adsorption of $\mathrm{O}_{2}$ on the oxygen vacancy oxidizes $\mathrm{Fe}^{2+}$ to $\mathrm{Fe}^{3+}$. Consequently, $\mathrm{NH}_{3}$ adsorbs stronger on the surface in the 
presence of co-adsorbed $\mathrm{O}_{2}\left(\Delta \mathrm{E}_{\mathrm{ads}}, \mathrm{NH} 3=-1.25 \mathrm{eV}\right)$ than in its absence $\left(\Delta \mathrm{E}_{\mathrm{ads}}, \mathrm{NH} 3=\right.$ $-0.66 \mathrm{eV})$ (Figure 8b). Also NO adsorption is stronger on $\mathrm{Fe}^{3+}\left(\Delta \mathrm{E}_{\mathrm{ads}, \mathrm{NO}}=-2.15 \mathrm{eV}\right)$ than on $\mathrm{Fe}^{2+}\left(\Delta \mathrm{E}_{\text {ads, }} \mathrm{NO}=-0.28 \mathrm{eV}\right)$ (Figure $\left.8 \mathrm{~b}\right)$. Both effects are expected to increase the rate of the NO SCR reaction.

The catalytic cycle continues by reaction of the nitrite species with adsorbed ammonia. First, one of the N-H bonds of chemisorbed $\mathrm{NH}_{3}$ is activated by a basic $\mathrm{O}$ atom to form adsorbed $\mathrm{OH}$ and $\mathrm{NH}_{2}$ surface species. Because of its higher basicity, $\mathrm{H}$ abstraction by a ceria lattice $\mathrm{O}^{2-}$ ion is preferred (state $\mathrm{v}, \Delta \mathrm{E}_{\text {reaction }}=0.99 \mathrm{eV}$ ) over abstraction by co-adsorbed $\mathrm{O}_{2}^{2-}$ (state $\mathrm{v}^{\prime}$ represented in Figure $9, \Delta \mathrm{E}_{\text {reaction }}=1.55 \mathrm{eV}$ ). The resulting $\mathrm{NH}_{2}$ radical will then react with $\mathrm{NO}$ to form $\mathrm{ONNH}_{2}$ as a reactive intermediate. The activation barrier for this process is very low $\left(\Delta \mathrm{E}_{\text {barrier }}=0.21 \mathrm{eV}\right)$. For the decomposition of this complex, we follow the mechanism identified in gas phase cluster studies of $\mathrm{VO}_{3}$ and $\mathrm{V}_{2} \mathrm{O}_{5}$ with $\mathrm{NO}$ and $\mathrm{NH}_{3} .{ }^{68-70}$ By abstraction of another $\mathrm{H}$ atom and proton transfer from the $\mathrm{OH}$ group $\left(\Delta \mathrm{E}_{\text {reaction }}=0.92 \mathrm{eV}\right)$, the HONNH surface intermediate is obtained, which weakly binds via its $\mathrm{OH}$ moiety to the Fe site (state vii, $\Delta \mathrm{E}_{\mathrm{ads}}=0.20 \mathrm{eV}$ ). Such intermediates are very unstable ${ }^{71}$ and decompose without activation barrier to gaseous $\mathrm{N}_{2}$ and, in this case, two $\mathrm{OH}$ groups, one of them bridging between two Ce ions and one coordinating to the Fe cation (state viii). These reaction events are very exothermic $\left(\Delta \mathrm{E}_{\text {reaction }}=-3.76 \mathrm{eV}\right)$. The surface then contains three $\mathrm{OH}$ groups (the three $\mathrm{H}$ atoms originate from ammonia, the $\mathrm{O}$ atom one of the $\mathrm{OH}$ groups from $\mathrm{NO}$ ). One $\mathrm{OH}$ group and one proton are removed as 
water (state ix, $\Delta \mathrm{E}_{\text {des }}=1.4 \mathrm{eV}$ ). The proton left behind will remove an $\mathrm{O}$ atom from the surface as water together with another proton obtained in a subsequent similar reaction cycle. The energetics of subsequent cycles should be very similar to the above-described cycle. ${ }^{72}$ Finally, the resulting $\mathrm{O}$ vacancies will be filled by dissociating $\mathrm{O}_{2}$. Taken together, these reactions amount to the overall $4 \mathrm{NO}+4 \mathrm{NH}_{3}$ $+\mathrm{O}_{2} \rightarrow 4 \mathrm{~N}_{2}+6 \mathrm{H}_{2} \mathrm{O}$ reaction stoichiometry. The potential energy diagram for the formation of the first part of the cycle is shown in Figure 9. Candidate rate-controlling steps are the two proton abstraction steps (iv $\rightarrow \mathrm{v}$ and vi to $\rightarrow$ vii) and water desorption (ix $\rightarrow \mathrm{x}$ ). As the latter step is facilitated by the entropy gain of water desorbing from the surface. Therefore, the present data suggest that the proton abstraction steps from ammonia to the ceria surface are the most likely reaction steps that control the overall reaction rate.

A second aspect of doping ceria with Fe relates to the oxidation of soot. Routine soot oxidation in CDPF is done before $\mathrm{NO}$ reduction, because $\mathrm{NO}_{2}$ produced by $\mathrm{NO}$ oxidation in the first step is a stronger oxidant than $\mathrm{O}_{2}$. To evaluate the influence of NO removal during soot oxidation, we carried out a soot oxidation experiment without $\mathrm{NO}$ and $\mathrm{NH}_{3}$ in the feed (Figure $\mathrm{S} 13$ ). The activity of the catalyst was slightly lower in this way, as evidenced by the small shift of the $\mathrm{CO}_{2}$ production maximum to higher temperature $\left(405^{\circ} \mathrm{C}\right)$. Nevertheless, the performance of the $\mathrm{Ce}_{0.8} \mathrm{Fe}_{0.1} \mathrm{Zr}_{0.1} \mathrm{O}_{2}$ catalyst under these conditions was still outstanding compared to reference systems. This result implies that the substitution of Fe into the ceria surface leads to activated 
oxygen species that are involved in the oxidation of soot. Although a thorough computational analysis of these aspects is beyond the scope of this study, electronic analysis of adsorbed $\mathrm{O}_{2}$ on the defective Fe-substituted ceria model (state i) and stoichiometric ceria shows nearly similar energetics with a formal $\mathrm{O}_{2}^{-}$state. However, comparison of the density of states (Figure S14) shows more O $2 \mathrm{p}$ states close to the Fermi level for $\mathrm{O}_{2}$ adsorbed on the defective $\mathrm{Fe}$-substituted ceria model, which will enhance oxidation of aromatics. Another relevant aspect is the much higher density of $\mathrm{O}$ vacancies in $\mathrm{Fe}$-doped ceria as compared with the stoichiometric ceria surface, which should also contribute significantly to the improved soot oxidation performance. 


\section{CONCLUSIONS}

We demonstrate that 3DOM mixed Fe-Ce-Zr-oxides are suitable for the simultaneous oxidation of soot and selective catalytic reduction of NOx in SCRPF technology. NO is reduced by $>90 \%$ and soot is completely combusted in the $265^{\circ} \mathrm{C}-420^{\circ} \mathrm{C}$ temperature range. The addition of $\mathrm{Fe}$ and $\mathrm{Zr}$ to ceria lowers the temperature of soot combustion to a level that is typically achieved by more expensive Pt catalysts. The 3DOM texture is suitable for trapping soot particles, while the presence of $\mathrm{Fe}$ in the ceria surface gives rise to high activity in NOx reduction and soot oxidation at intermediate temperatures. The importance of the open macroporous 3DOM texture in soot capture and combustion was demonstrated by comparison to a mesoporous mixed oxide of the same composition. Surface characterization and DFT calculations show that substitution of $\mathrm{Fe}$ in the structured mixed $\mathrm{Ce}-\mathrm{Zr}$-oxide increased the number of oxygen vacancies. A mechanism is explored for the reduction of $\mathrm{NO}$ with $\mathrm{NH}_{3}$ involving adsorbed $\mathrm{O}_{2}$ as a catalytic surface intermediate. Such adsorbed $\mathrm{O}_{2}$ species may also be important in soot oxidation. These structured mixed oxides may find application in diesel particulate filters, e.g., by inclusion in wall flow filters constituting of ceramic honeycomb structures plugged to force the exhaust flow through the walls. One may for instance consider to integrate the here developed mixed oxide with the base corderite ceramic used in such filters.

\section{AUTHOR INFORMATION}

\section{Corresponding Authors}

* Tel: (+86)10-89732778; Email: liujian@ @up.edu.cn (J. L.) 
* Tel: (+31)40-2455054; Email: E.J.M.Hensen@ TUE.nl (E. H.).

* Tel: (+86)10-89732326; Email: zhaozhen@ synu.edu.cn; (Z. Z.).

\section{Author Contributions}

† Y. C. and W. S. contributed equally to this work.

\section{Notes}

The authors declare no competing financial interest.

\section{SUPPORTING INFORMATION}

Figure S1-S14 and Table S1-S2. The materials are available free of charge.

\section{ACKNOWLEDGMENT}

This work was financially supported by the National Natural Science Foundation of China (21673290, 21503273 and U1662103) and the 863 Program (2015AA034603). EJMH acknowledges support of a VICI grant by the Netherlands Organization for Scientific Research.

\section{REFERENCES}

(1) Niessner, R. Angew. Chem. Int. Ed. 2014, 53, 12366-12379.

(2) Megarajan, S. K.; Rayalu, S.; Nishibori, M.; Teraoka, Y.; Labhsetwar, N. ACS Catal. 2014, 5, 301-309.

(3) Kimura, R.; Wakabayashi, J.; Elangovan, S. P.; Ogura, M.; Okubo, T. J. Am. Chem. Soc. 2008, 130, 12844-12845.

(4) Zhao, Y.; Hao, R.; Yuan, B.; Jiang, J. J. Hazard. Mater. 2016, 301, 74-83. 
(5) Tsinoglou, D. N.; Koltsakis, G. C.; Peyton Jones, J. C. Ind. Eng. Chem. Res. 2002, $41,1152-1165$.

(6) Matarrese, R.; Morandi, S.; Castoldi, L.; Villa, P.; Lietti, L. Appl. Catal. B 2017, 201, 318-330.

(7) Teraoka, Y.; Kanada, K.; Kagawa, S. Appl. Catal. B 2001, 34, 73-78.

(8) Yoshida, K.; Makino, S.; Sumiya, S.; Muramatsu, G.; Helferich, R. Simultaneous reduction of NOx and particulate emissions from diesel engine exhaust, SAE Technical Paper, 1989.

(9) Teraoka, Y.; Shangguan, W.; Jansson, K.; Nygren, M.; Kagawa, S. Bull. Chem. Soc. Jpn. 1999, 72, 133-137.

(10) Zhang, H.-L.; Zhu, Y.; Wang, S.-D.; Zhao, M.; Gong, M.-C.; Chen, Y.-Q. Fuel Process. Technol. 2015, 137, 38-47.

(11) Liu, S.; Wu, X.; Weng, D.; Li, M.; Lee, H.-R. Chem. Eng. J. 2012, 203, 25-35.

(12) Parks, J. E. Science 2010, 327, 1584-1585.

(13) Cortés-Reyes, M.; Herrera, C.; Larrubia, M. Á.; Alemany, L. J. Appl. Catal. B 2016, 193, 110-120.

(14) Marberger, A.; Ferri, D.; Elsener, M.; Kröcher, O. Angew. Chem. Int. Ed. 2016, $55,11989-11994$.

(15) Wang, Z.; Yan, X.; Bi, X.; Wang, L.; Zhang, Z.; Jiang, Z.; Xiao, T.; Umar, A.; Wang, Q. Mater. Res. Bull. 2014, 51, 119-127.

(16) Raj, A.; Zainuddin, Z.; Sander, M.; Kraft, M. Carbon 2011, 49, 1516-1531.

(17) El Kadib, A.; Chimenton, R.; Sachse, A.; Fajula, F.; Galarneau, A.; Coq, B. Angew. Chem. 2009, 121, 5069-5072.

(18) Wei, Y.; Liu, J.; Zhao, Z.; Chen, Y.; Xu, C.; Duan, A.; Jiang, G.; He, H. Angew. Chem. Int. Ed. 2011, 50, 2326-2329.

(19) Peng, Q.; Zhao, H.; Qian, L.; Wang, Y.; Zhao, G. Appl. Catal. B 2015, 174-175, 157-166.

(20) Yang, C.; Yu, X.; Heißler, S.; Nefedov, A.; Colussi, S.; Llorca, J.; Trovarelli, A.; Wang, Y.; Wöll, C. Angew. Chem. Int. Ed. 2017, 56, $2-2$. 
(21) Rout, K. R.; Fenes, E.; Baidoo, M. F.; Abdollahi, R.; Fuglerud, T.; Chen, D. ACS Catal. 2016, 6, 7030-7039.

(22) Cargnello, M.; Jaén, J. D.; Garrido, J. H.; Bakhmutsky, K.; Montini, T.; Gámez, J. C.; Gorte, R.; Fornasiero, P. Science 2012, 337, 713-717.

(23) Gao, Y.; Wu, X.; Liu, S.; Weng, D.; Zhang, H.; Ran, R. Catal. Today 2015, 253, 83-88.

(24) Liu, J.; Zhao, Z.; Wang, J.; Xu, C.; Duan, A.; Jiang, G.; Yang, Q. Appl. Catal. B 2008, $84,185-195$.

(25) Giménez-Mañogil, J.; Bueno-López, A.; García-García, A. Appl. Catal. B 2014, 152-153, 99-107.

(26) Neyertz, C. A.; Banús, E. D.; Miró, E. E.; Querini, C. A. Chem. Eng. J. 2014, 248, 394-405.

(27) Atribak, I.; Buenolopez, A.; Garciagarcia, A. J. Catal. 2008, 259, 123-132.

(28) Cai, S.; Zhang, D.; Zhang, L.; Huang, L.; Li, H.; Gao, R.; Shi, L.; Zhang, J. Catal. Sci. Technol. 2014, 4, 93-101.

(29) Arandiyan, H.; Dai, H.; Ji, K.; Sun, H.; Li, J. ACS Catal. 2015, 5, 1781-1793.

(30) Yu, J.; Si, Z.; Chen, L.; Wu, X.; Weng, D. Appl. Catal. B 2015, 163, 223-232.

(31) Wei, Y.; Liu, J.; Zhao, Z.; Duan, A.; Jiang, G.; Xu, C.; Gao, J.; He, H.; Wang, X. Energy \& Environ. Sci. 2011, 4, 2959-2970.

(32) Trasobares, S.; López - Haro, M.; Kociak, M.; March, K.; de La Peña, F.; Perez - Omil, J. A.; Calvino, J. J.; Lugg, N. R.; D'Alfonso, A. J.; Allen, L. J. Angew. Chem. Int. Ed. 2011, 50, 868-872.

(33) Aneggi, E.; de Leitenburg, C.; Dolcetti, G.; Trovarelli, A. Catal. Today 2006, 114, 40-47.

(34) Li, G.; Smith, R. L.; Inomata, H. J. Am. Chem. Soc. 2001, 123, 11091-11092.

(35) Xu, J.; Liu, J.; Zhao, Z.; Xu, C.; Zheng, J.; Duan, A.; Jiang, G. J. Catal. 2011, $282,1-12$.

(36) Zhang, G.; Zhao, Z.; Xu, J.; Zheng, J.; Liu, J.; Jiang, G.; Duan, A.; He, H. Appl. Catal. B 2011, 107, 302-315. 
(37) Cao, X.; Zheng, B.; Rui, X.; Shi, W.; Yan, Q.; Zhang, H. Angew. Chem. Int. Ed. 2014, 53, 1404-1409.

(38) Qin, D.; Cadet, G. Anal. Chem. 1997, 69, 1942-1945.

(39) Perdew, J. P.; Burke, K.; Ernzerhof, M. Phys. Rev. Lett. 1996, 77, 3865.

(40) Blöchl, P. E. Phys. Rev. B 1994, 50, 17953.

(41) Kresse, G.; Joubert, D. Phys. Rev. B 1999, 59, 1758.

(42) Da Silva, J. L. F.; Ganduglia-Pirovano, M. V.; Sauer, J.; Bayer, V.; Kresse, G. Phys. Rev. B 2007, 75, 045121-045110.

(43) Fabris, S.; de Gironcoli, S.; Baroni, S.; Vicario, G.; Balducci, G. Phys. Rev. B 2005, 72, 237102.

(44) Cococcioni, M.; de Gironcoli, S. Phys. Rev. B 2005, 71, 035105-035116.

(45) Castleton, C.; Kullgren, J.; Hermansson, K. J. Chem. Phys. 2007, 127, 244704-244704.

(46) Huang, X.; Ramadugu, S. K.; Mason, S. E. J. Phys. Chem. C 2016, 120, 4919-4930.

(47) Henkelman, G.; Uberuaga, B. P.; Jónsson, H. J. Chem. Phys. 2000, 113, 9901-9904.

(48) Orilall, M. C.; Abrams, N. M.; Lee, J.; DiSalvo, F. J.; Wiesner, U. J. Am. Chem. Soc. 2008, 130, 8882-8883.

(49) Yang, J.; Yang, Z.; Wang, Y.; Li, J.; Shao, B.; Qiu, J.; Song, Z.; Frenc, R. H. J. Am. Ceram. Soc. 2015, 98, 2011-2013.

(50) Magnacca, G.; Cerrato, G.; Morterra, C.; Signoretto, M.; Somma, F.; Pinna, F. Chem. Mater. 2003, 15, 675-687.

(51) Zhan, S.; Zhang, H.; Zhang, Y.; Shi, Q.; Li, Y.; Li, X. Appl. Catal. B 2017, 203, 199-209.

(52) dos Santos Xavier, L. P.; Rico-Pérez, V.; Hernández-Giménez, A. M.; Lozano-Castelló, D.; Bueno-López, A. Appl. Catal. B 2015, 162, 412-419.

(53) Perry, R. A.; Siebers, D. L. Nature 1986, 324, 657-658.

(54) Boubnov, A.; Carvalho, H. W.; Doronkin, D. E.; Gunter, T.; Gallo, E.; Atkins, A. 
J.; Jacob, C. R.; Grunwaldt, J. D. Journal of the American Chemical Society 2014, 136, 13006-13015.

(55) Heylen, S.; Delcour, N.; Kirschhock, C. E. A.; Martens, J. A. ChemCatChem 2012, 4, 1162-1166.

(56) Liu, Z.; Wakihara, T.; Oshima, K.; Nishioka, D.; Hotta, Y.; Elangovan, S. P.; Yanaba, Y.; Yoshikawa, T.; Chaikittisilp, W.; Matsuo, T.; Takewaki, T.; Okubo, T. Angew. Chem. Int. Ed. 2015, 54, 5683-5687.

(57) Paolucci, C.; Verma, A. A.; Bates, S. A.; Kispersky, V. F.; Miller, J. T.; Gounder, R.; Delgass, W. N.; Ribeiro, F. H.; Schneider, W. F. Angew. Chem. Int. Ed. 2014, $53,11828-11833$.

(58) Mou, X.; Zhang, B.; Li, Y.; Yao, L.; Wei, X.; Su, D. S.; Shen, W. Angew. Chem. Int. Ed. 2012, 51, 2989-2993.

(59) Shan, W.; Liu, F.; He, H.; Shi, X.; Zhang, C. Chem. Commun. 2011, 47, 8046-8048.

(60) Li, J.; Zhu, R.; Cheng, Y.; Lambert, C. K.; Yang, R. T. Environ. Sci. Technol. 2010, 44, 1799-1805.

(61) Liu, S.; Wu, X.; Weng, D.; Li, M.; Ran, R. ACS Catal. 2015, 5, 909-919.

(62) Wang, H.; Qu, Z.; Xie, H.; Maeda, N.; Miao, L.; Wang, Z. J. Catal. 2016, 338, $56-67$.

(63) Kureti, S.; Weisweiler, W.; Hizbullah, K. Appl. Catal. B 2003, 43, 281-291.

(64) Wang, H.-F.; Gong, X.-Q.; Guo, Y.-L.; Guo, Y.; Lu, G. Z.; Hu, P. J. Phys. Chem. C 2009, 113, 10229-10232.

(65) Mayernick, A. D.; Janik, M. J. J. Phys. Chem. C 2008, 112, 14955-14964.

(66) Kim, H. Y.; Lee, H. M.; Henkelman, G. J. Am. Chem. Soc. 2012, 134, 1560-1570.

(67) Zhang, Z.; Han, D.; Wei, S.; Zhang, Y. J. Catal. 2010, 276, 16-23.

(68) Walch, S. P. J. Chem. Phys. 1993, 99, 5295-5300.

(69) Duan, X.; Page, M. J. Mol. Struct.THEOCHEM 1995, 333, 233-242.

(70) Soyer, S.; Uzun, A.; Senkan, S.; Onal, I. Catal. Today 2006, 118, 268-278. 
(71) Phillips, L. Chem. Phys. Lett. 1987, 135, 269-274.

(72) Song, W.; Liu, J.; Zheng, H.; Ma, S.; Wei, Y.; Duan, A.; Jiang, G.; Zhao, Z.; Hensen, E. J. Catal. Sci. Technol. 2016, 6, 2120-2128.

\section{Table of Contents}

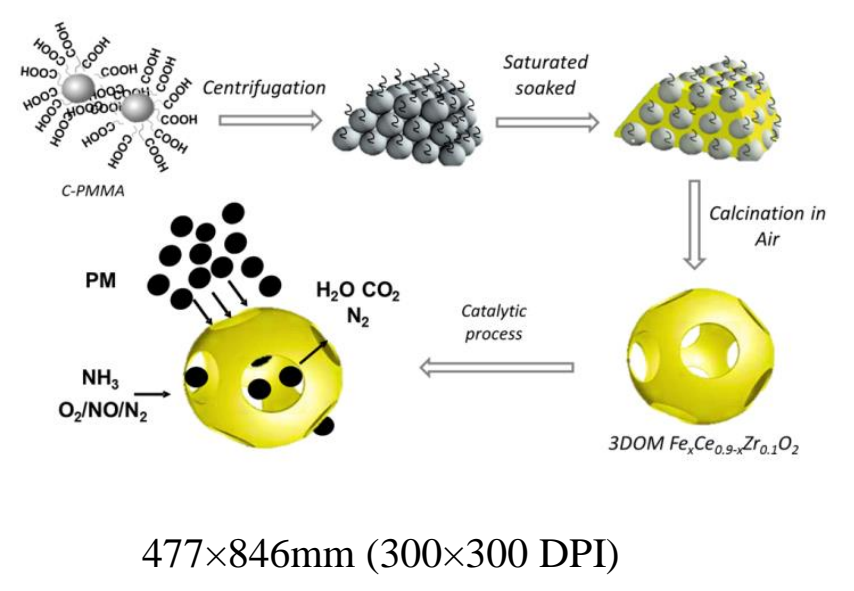

A selective catalytic reduction and particular filter is proposed in which NOx and soot are simultaneously removed from diesel exhaust using a $\mathrm{Ce}_{0.8} \mathrm{Fe}_{0.1} \mathrm{Zr}_{0.1} \mathrm{O}_{2}$ catalyst possessing a unique macroporous structure conducive to the capture of soot particles, abundant oxygen vacancies obtained by Fe doping which give rise to high activity in NOx reduction and soot oxidation. 

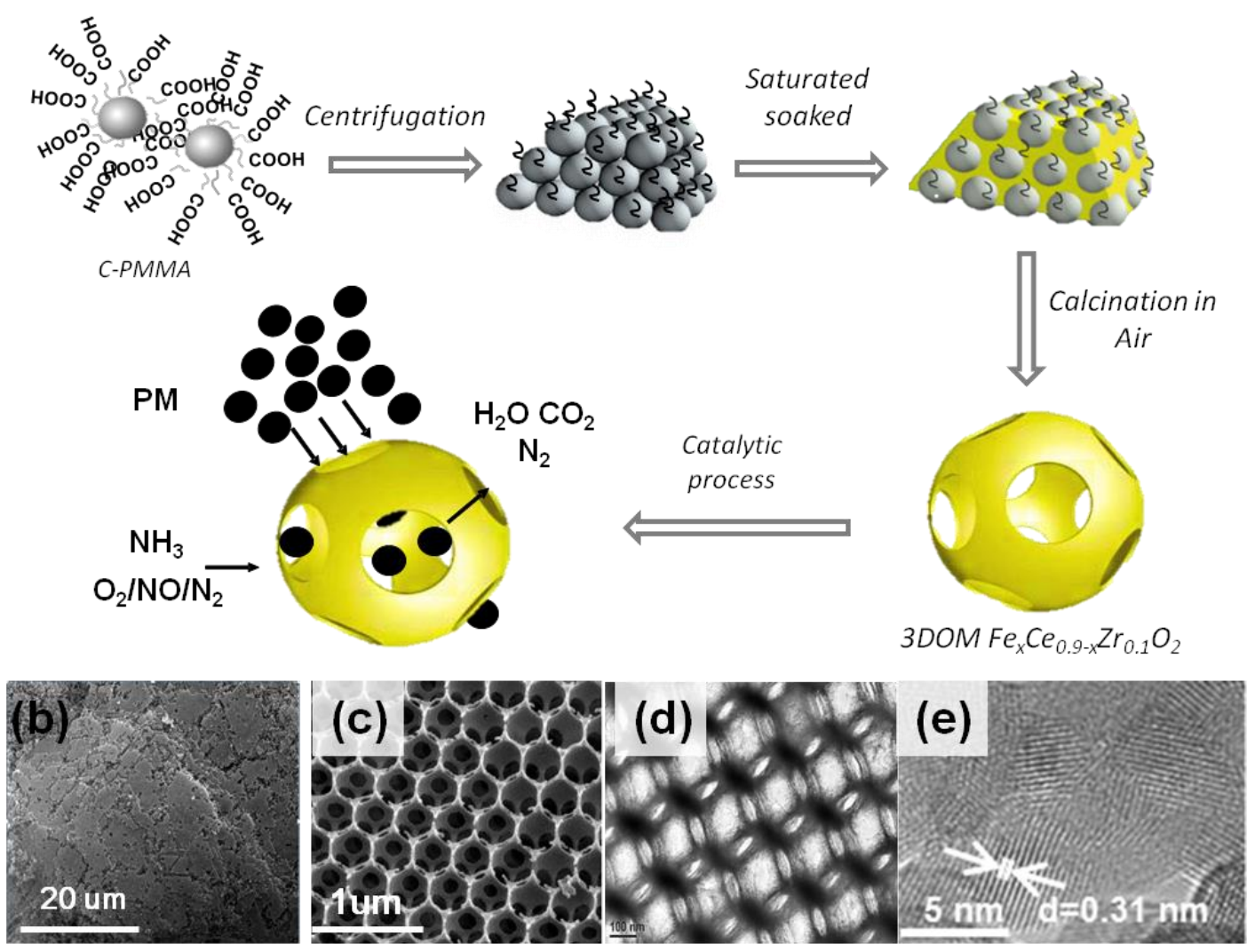

$111 \times 146 \mathrm{~mm}(300 \times 300 \mathrm{DPI})$ 